Copyright (C) 2021 by Cherkas Global University

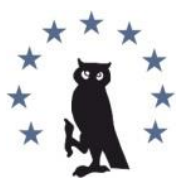

Published in the USA

Russkaya Starina

Has been issued since 2010.

E-ISSN: 2409-2118

2021. 12(2): 155-172

DOI: $10.13187 / \mathrm{rs} .2021 .2 .155$

https://rs.cherkasgu.press

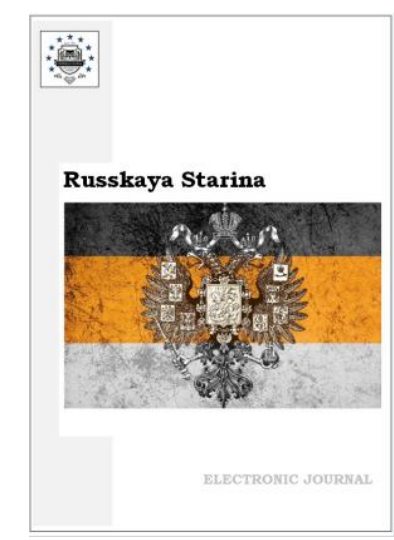

\title{
Don Cossack Celebration of St. John's Day: Chrononyms and Ritual Actions
}

\author{
Nina A. Vlaskina a, * \\ a Federal Research Centre the Southern Scientific Centre of the Russian Academy of Sciences, \\ Russian Federation
}

\begin{abstract}
The article presents an analysis of the vocabulary, rituals and beliefs of the Day of St. John the Baptist (Midsummer) among the Don Cossacks and peasants. The empirical basis of the study was a sample of 126 detailed texts and short judgments recorded in 28 districts of the Rostov region and 11 districts of the Volgograd region. The text sequentially examines: the main elements of the Kupala rituals in European traditions (East Slavic included); the main symbolic dominants of this day in the Don region (water symbols, rituals associated with greenery, lighting fires, religious component). The author provides the characteristic of the symbolic connections of St. John's Day in the Don tradition with the days of Elijah the Prophet and Simon the Zealot, the Pentecost, the occasional rite of making rain. The author comes to the conclusion that, in general, the Don version of St. John's celebration is closer to that characteristic of Russian regions, but the specificity of actions with water is the leading pragmatics of making rain. At the same time, detailing and representativeness of the texts about St. John's celebration in territories with a significant proportion of the Ukrainian population shows that the powerful cultural layer of the holiday that existed in the Ukrainian tradition was not eroded even after the resettlement to the Don region.
\end{abstract}

Keywords: bathing, Don Cossacks, Don peasants, dousing, ethnic interaction, greenery, Russians, St. John the Baptist, traditional culture, Ukrainians.

\section{1. Введение}

День летнего солнцеворота с древних времен имел особое значение для земледельцев как момент наивысшего расцвета природы. Вместе с днем зимнего солнцестояния он делил год на два равных отрезка и потому наделялся символическим смыслом в традициях многих европейских народов (Frazer 2009: 1453-1476). В христианском календаре ему близок день Рождества Иоанна Предтечи (24.06/07.07), который с распространением христианства вобрал в себя символику народного праздника (Соколова, 1979: 228). В европейских традициях его типичными составляющими были «зажжение костров, якобы обладающих очистительной силой; действия, связанные с водой, так же как с очистительным средством; гадания о судьбе людей; соревнования как ритуальный комплекс очищения и пропициации (умилостивления); поверья о существах преисподней, бродящих якобы в этот день по земле» (Красновская, 1978: 10). В Литве, Латвии и Эстонии Иванов день и сейчас является

\footnotetext{
${ }^{*}$ Corresponding author

E-mail addresses: nvlaskina@gmail.com (N.A. Vlaskina)
} 
официальным выходным днем, что говорит о его высоком статусе в ритуальном годе (Paukštytè-Šaknienè, 2016: 286).

Славянская обрядность Иванова дня и предшествующей ему ночи, будучи частью европейской, включает те же группы ритуальных действий. Наряду с ними Л.Н. Виноградова и С.М. Толстая в самостоятельные группы акций выделяют ночные бесчинства и поверья об «игре» солнца и других чудесах природы (Виноградова, Толстая, 1999: 363). В ряде регионов Восточной Славии, где проводилось сплошное этнографическое обследование, элементы названных выше действий фиксировались вплоть до середины XX в. (Корепова, 2009: 351-358; Красиков и др., 1998: 27-37; Махрачёва, Шлыкова, 2020; Пашина, 2003: 343-353; Толстая, 1978; Черных, 2006 и др.). Сказанное относится и к зонам, контактным с Ростовской и Волгоградской областью (Бондарь, 2011: 212-221; Пухова, Христова, 2005: 117-121).

В свою очередь, на территории бывшей Области войска Донского (далее - ОВД) обряды Иванова дня наследуют традициям метропольных территорий - южнорусских и малороссийских губерний, это один из тех праздников, в которых отсутствовала воинская компонента.

К рубежу XX-XXI вв. купальская обрядность сохранилась в основном в воспоминаниях, отражающих реалии 1930-1970-х гг. (самая ранняя фиксация материалы корреспондента «Донских областных ведомостей» 1876 г. (Р., 1876), ряд свидетельств описывают реалии начала XX в.). В настоящей статье ставится задача обобщить и картографировать доступные этнографические материалы по верованиям и обрядам, относящимся к Иванову дню, на территории бывшей Области войска Донского.

\section{2. Материалы и методы}

В статье анализируются сведения о праздновании Иванова дня в донском регионе из нескольких типов источников. Самую большую группу составили материалы диалектологических и этнолингвистических экспедиций Южного федерального университета (до 2006 г. - Ростовского государственного университета) и Южного научного центра Российской академии наук, собранные в 1990-2014 гг. в Ростовской и Волгоградской областях. Были также использованы труды этнографов и краеведов, изучавших традиционную культуру казаков и крестьян на территории бывшей ОВД (Апраксин, 2012: 318-319, 321; Р., 1876; Рыблова, 2014: 124-125; Пальгов, Шилкин, 2020: 84-85), а также словари донских говоров (БТСДК; СДГВО).

Объектом исследования стал корпус явлений традиционной культуры, включающий хрононимы и другую календарно приуроченную диалектную лексику, былички, легенды, приметы, поверья, гадания, клишированные запреты и предписания, устойчивые выражения, календарные песни, описания праздников и обрядов. Объем выборки составил 126 развернутых текстов и кратких суждений из 28 районов Ростовской ${ }^{1}$ и 11 районов Волгоградской области ${ }^{2}$. Исследование проводилось с использованием сравнительноисторического и этнолингвистического методов, а также методов текстологического анализа и картографирования.

\footnotetext{
${ }^{1}$ Азовский (далее - Азов.), Багаевский (далее - Баг.), Боковский (далее - Бок.), Верхнедонской (далее - В.-Дон.), Веселовский (далее - Вес.), Волгодонской (далее - Волгод.), Дубовский (далее Дуб.), Заветинский (далее - Зав.), Зимовниковский (далее - Зим.), Кагальницкий (далее - Каг.), Каменский (далее - Кам.), Константиновский (далее - Конст.), Миллеровский (далее - Милл.), Милютинский (далее - Милют.), Морозовский (далее - Мор.), Обливский (далее - Обл.), Октябрьский (далее - Окт.), Орловский (далее - Орл.), Пролетарский (далее - Прол.), Ремонтненский (далее - Рем.), Семикаракорский (далее - Сем.), Советский (далее - Сов.), Тарасовский (далее - Тар.), Тацинский (далее - Тац.), Усть-Донецкий (далее - У.-Дон.), Цимлянский (далее - Цимл.), Чертковский (далее - Черт.), Шолоховский (далее - Шол.) районы Ростовской области (далее - РО).

2 Алексеевский (далее - Алек.), Даниловский (далее - Дан.), Иловлинский (далее - Илов.), Котельниковский (далее - Кот.), Кумылженский (далее - Кум.), Михайловский (далее - Мuх.), Нехаевский (далее - Hех.), Новоаннинский (далее - Н.-Анн.), Суровикинский (далее - Сур.), Урюпинский (далее - Урюп.), Чернышковский (далее - Черн.) районы Волгоградской области (далее - ВО).
} 


\section{3. Обсуждение и результаты}

Основнье элементъц купальской обрядности. Как отмечает В.К. Соколова, в различных частях восточнославянского ареала уже в XIX в. купальская обрядность и фольклор были представлены неравномерно: больше архаических элементов сохранили белорусы и украинцы, в то время как в различных русских регионах ритуалы Иванова дня преимущественно редуцировались до отдельных элементов, не связанных между собой полноценным ритуалом (Соколова, 1979: 230). В то же время и в самой России степень сохранности этих элементов была разной: в одних ее областях, например, в Нижегородской или Пермском крае, «хорошо сохранялись многие или даже почти все элементы купальской обрядности, но не в комплексе, а дискретно» (Корепова, 2009: 352). В других (в Воронежской, Тамбовской областях и др.) о бытовавших практиках и верованиях свидетельствуют лишь краткие мемораты и суждения, в третьих (например, на Южном Урале (Рожкова, Моисеева, 2003)) воспоминания о купальской обрядности не сохранились до наших дней.

Обрядовые действия Иванова дня у донских казаков и крестьян по полноте бытования и фиксации можно причислить, скорее, ко второй группе. В донском народном календаре этот день оказался на периферии круга значимых дат. Как отмечала одна из собеседниц, «на Купала я табе скажу так: праздник маленький, яво не здорово. До обеда яво праздновали. А после обеда уж работали люди»' (записано (далее - зап.) от А.М. Котовской, 1910 года рождения (далее - г.р.), в пос. Нижний Чир Сyp. ВО в 1993 г., собиратель (далее - соб.) Кравченко) (ПМДЭЭ ЮФУ - ЮНЦ РАН: п. 61, т. 4).

Как и в других русских регионах, в казачьих станицах и хуторах ОВД большей популярностью обладала Троица, входившая в перечень двунадесятых праздников православного календаря. Значительная часть обрядов и поверий, связанных с зеленью, была приурочена именно к ней (см. подробнее: Власкина, 2017). Как представляется, облик Иванова дня в донской традиции, восстанавливаемый по записываемым в последние десятилетия рассказам, зависим и от факторов поздней фиксации, когда процессы утраты традиции стали активными и повсеместными, а также от переселенческого характера донской культуры, которая выборочно сохраняла элементы метропольных традиций.

Рассмотрим далее обрядовые действия и представления об Ивановом дне, обеспеченные в анализируемом регионе репрезентативным материалом.

Иванов день на Дону: водная символика. Наиболее устойчивой в донской традиции оказалась водная символика праздника ${ }^{2}$. Воспоминания о тех или иных действиях с водой были записаны в большинстве районов, откуда получена развернутая информация об Ивановом дне. На наш взгляд, одним из факторов сохранности именно этого смысла стало закрепление символа в названии праздника. В ситуации редукции компонентов традиции и утраты символического обоснования действий название служит якорем, который удерживает мифологические представления в активной памяти носителей культуры. Роль народной этимологии как мотивирующей и генерирующей, порождающей обрядовые действия была подробно рассмотрена Н.И. и С.М. Толстыми (Толстой, Толстая, 2013). Наряду с общерусским хрононимом Иван Купала в рассматриваемом регионе встречены также Иван Купайла (х. Донской Азов., ст. Обливская Обл., ст. Раздорская У.-Дон.), Иванка Купала (пос. Зимовники Зим.), Иван Купальный (ст. Малая Лучка Дуб., х. Грузинов Мор., х. Боровки Илов., х. Большой Мих., х. Лысов, Бурацкий, пос. Нижний Чир Сур., х. Фирсовка, Тормосин Черн.), Купальный день (х. Лысов Сур.).

В многочисленных контекстах респонденты используют для обозначения ритуальных действий именно глаголы купать, купаться: «На Ивана Купала ходылы купаться» (зап. от А. Коваленко, 1930-х г.р., в с. Кагальник Азов. РО) (ПМА); «На Ивана Купала купаются» (зап. от А.П. Колесниковой, 1918 г.р., в ст. Кагальницкой Каг. РО в 2006 г., соб. К. Лонская) (ПМДЭЭ ЮФУ - ЮНЦ РАН: П. 110, т. 5); «На Ивана Купала купались, обливалисъ» (зап. от

\footnotetext{
${ }^{1}$ Здесь и далее диалектные тексты приводятся в орфографической записи с сохранением отдельных фонетических черт, присущих донским говорам.

2 Обливание водой и купание как основные составляющие купальской обрядности в населенных пунктах Волоградской области выделяют на своем материале также С.Ю. Пальгов, В.А. Шилкин (Пальгов, Шилкин, 2020: 84) и М.А. Рыблова (Рыблова, 2014: 124).
} 
К.И. Суховой, 1941 г.р., в х. Грузинове Мор. РО в 2009 г., соб. М. Кабакова) (ПМДЭЭ ЮФУ ЮНЦ РАН: п. 98, т. 10). В ст. Мальчевской Милл., Кочетовской Сем., х. Новороссошанском Tац., х. Орлы Mux. праздник считался датой, с которой разрешалось купание ${ }^{1}$.

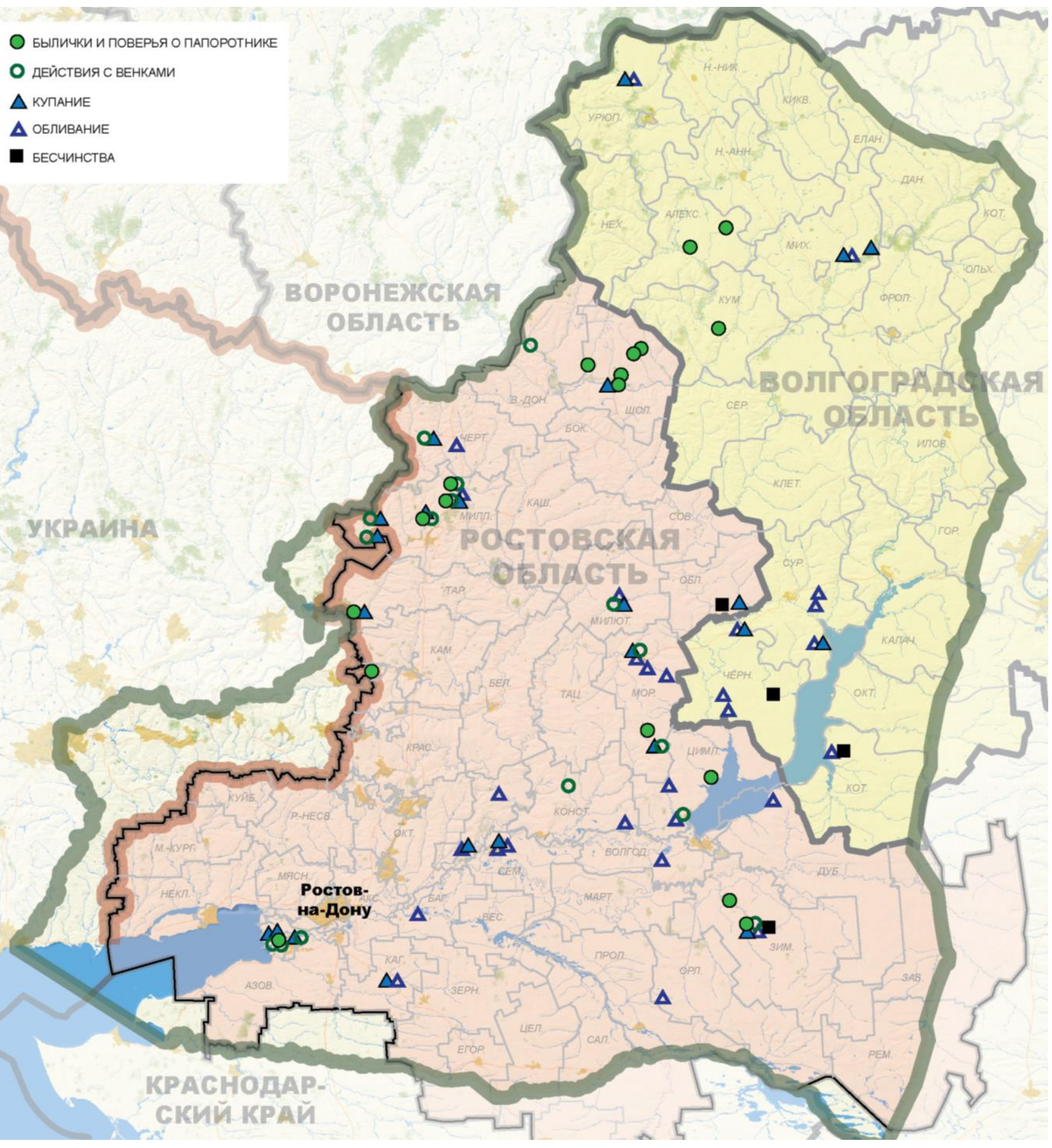

Рис. 1. Ритуальные действия в день Ивана Купалы и тексты, их описывающие, на территории бывшей Области войска Донского (сост. Н.А. Власкина)

1 В других населенных пунктах, наоборот, бытовал запрет на купание. По наблюдениям М.А. Рыбловой, в х. Остроухове Кум. запрет мотивировался тем, что пловца «русалки защекочат» (Рыблова, 2014: 125), в ст. Верхнекундрюченской У.-Дон. считали, что нарушивший запрет может утонуть (ПМДЭЭ ЮФУ: п. 84, т. 1). 
Анализ лексем, обозначающих действия с водой в Иванов день, показывает, что при их описании глагол купать не только обозначает 'погружать в воду', но и получает диалектное значение 'обливать водой' и используется как синоним глагола обливать, ср.: «В энтот день такая жара, и говорять: “Ивана Купайла, надо скупать всех”. А колодезь один был, одна тягаеть, а энтих за ним гонють, энта отсель ведром. А он в хату залез, а мы его в хате нашли, облили всё. И дош пошёл к вечеру. Вот ентим же и вызывали дош» (зап. от А.П. Громовой, 1909 г.р., в ст. Обливской Обл. РО в 1998 г., соб. Л.И. Гнутова) (ПМДЭЭ ЮФУ: п. 116, т. 2); «Мы вот уже детьми, ну сегодня Ивана Купала, давай купать - вёдрами воду один на одного. К Дону туда, обливаем. Кто придёт, всех вот обливали» (зап. от В.В. Качалиной, 1935 г.р., в ст. Раздорской У.-Дон. РО в 2001 г., соб. Е. Муштенко) (ПМДЭЭ ЮФУ: п. 56, т. 11). Так же и сами ритуальные действия купания и обливания часто сосуществуют в донских рассказах об Ивановом дне.

Свидетельства о купании в Иванов день были записаны в х. Донском, ст. Елизаветинской, с. Кагальник Азов., ст. Кагальницкой Каг., пос. Зимовники Зим., ст. Мальчевской, сл. Волошино, Колодези, Нижне-Нагольной Милл., х. Юдине Милют., х. Грузинове, Парамонове Мор., Сеньшине Обл., ст. Кочетовской Сем., Митякинской Тар., Раздорской У.-Дон., с. Маньково-Калитвенском Черт., ст. Вешенской Шол., х. Большом, Орлы Muх., пос. Нижний Чир Сур., х. Бубновском Урюп., х. Большетерновом Черн (Рисунок 1).

Об обливании рассказывали в ст. Манычской Баг., х. Потапове Волгод., ст. Малая Лучка Дуб., пос. Зимовники Зим., ст. Кагальницкой Каг., Мариинской Конст., сл. Колодези Милл., х. Юдине Милют., х. Грузинове, Донском, г. Морозовске Мор., х. Гундоровском Орл., ст. Кочетовской, х. Чебачьем Сем., ст. Верхнекундрюченской, Раздорской У.-Дон., Маркинской, Красноярской Цимл., Черт., х. Красноярском Кот., Большом Мuх., Лысове, Бурацком, пос. Нижний Чир Сур., х. Бубновском Урюп., Большетерновом, Фирсовке, Нижнегнутове Черн.

Локусом купания чаще всего становился ближний к населенному пункту водоем: река, пруд. Обливания могли совершаться как в пределах станицы, хутора, слободы (во дворе, даже в доме, на улице), так и за их границами: в поле.

Чаще всего, по воспоминаниям респондентов, в обливании участвовали все, кто хотел, но иногда упоминали особенно охотное участие в нем молодежи (например, в ст. Малая Лучка Дуб.). При этом ритуальное обливание приобретало форму игры, шутки. Приведем несколько колоритных описаний.

В ст. Кагальницкой Каг. парни старались облить девушек: «Вот Ивана Купала, вот будешь мимо идти, те да те искупають, шо будешь мокрый. Девочки - да они хоронилися, чтоб их не покупали ребята. Они ж не въххоили на улицу. Это же день сегодня примерно Ивана Купала, а назавтра уже можно выходить, уже завтра не будуть купать» (зап. от А.П. Колесниковой). В ст. Мариинской Конст.: «А тогда у нас ранъше на один день обливали водою. Иван Купала был. И вот мои родители позалезли, ну, тётка там, на эту крыльцо и сидять. Их же нихто не гонял. И они [те, кто обливал] влезли там сзади на баля сы и кругом. Пока они добежали, крыльцо большая, а наши вскощили в колидор. И не облили их» (зап. от Л.И. Дорминой, 1918 г.р., в 2005 г., соб. Н.С. Бондаренко) (ПМДЭЭ ЮФУ: п. 79а, т. 6). В х. Юдин Милют.: «Праздновали, о, это обливались страшно, не глядели, что ты идёшь нарядная, обольють. Ипять, какие, люди есть старые, подымуть, он идёть, а тут как начнуть, а хто убягаеть, поймають да в речку его тянуть, кинуть по воде яво» (зап. от А.Н. Карповой, 1910 г.р., в 1992 г., соб. И. Смирнова) (ПМДЭЭ ЮФУ: П. 40, т. 13).

Особого внимания заслуживает мотивировка действий с водой в этот день. В.К. Соколова (Соколова, 1979: 234), Л.Н. Виноградова и С.М. Толстая (Виноградова, Толстая, 1999: 365) указывают прежде всего на очистительную функцию купания и обливания, целительную силу воды в этот день, однако в рассматриваемом регионе такие мотивировки единичны. Традицию набирания воды в колодцах в полночь накануне Иванова дня и смешивания ее с крещенской водой отмечает М.А. Рыблова без указания населенного пункта (Рыблова, 2014: 125). Об особых свойствах купальской росы говорится в записанном в ст. Вёшенской Шол. предписании выгнать до рассвета скот в этот праздник, чтоб он был здоровым; там же говорили, что на рассвете нужно искупать детей, тогда они будут здоровыми, с чистой кожей (ПМДЭЭ ЮФУ: п. 67, т. 26). Целительную силу воды на 
Ивана Купалу упоминали в донской слободе с украинским по происхождению населением: «На Купалу. <...> Купаемось, облываемость, а у кого ни, так дома отак от, с шлангу, прыстрое шлангу, потянуть, облывалыся, смеются. <...> Надо, для здоровья полезно. Водычка ця для здоровъя». Но далее в рассказе собеседница вспоминает и о том, что обливание вызывало дождь: «И диты прыскають, як начнуть. Як то она раз и накупала, тай дощ пийшов. А у нас как повыскакувалы вси, детвора: хлюстаются, радуются, облываются. Попрыходылы у муляки: “Та шо ж вам!” - "Нычё, нычё”, шлангу протяглы, пообмывалысь» (зап. от П.И. Левченко, 1932 г.р., в сл. Колодези Милл. РО в 2011 г., соб. М.А. Карпун, Н.С. Бондаренко) (ПМДЭЭ ЮФУ - ЮНЦ РАН: п. 103, т. 1).

В целом же в большей части рассказов об обливании, записанных на территории бывшей ОВД, на первый план выходит магическая функция вызывания дождя: «Все же праздновали вроде бы, ну занимались, купали один одного, чтоб вроде дожди пошли» (зап. от К.С. Степанниковой, 1915 г.р., в пос. Нижний Чир Сур. ВО в 1993 г., соб. Кравченко) (ПМДЭЭ ЮФУ: п. 61, т. 4); «На Иван Купала <...> обливаться можно, чтоб хоть дощ пошёл» (зап. от К.Д. Бобырёвой, 1927 г.р., в ст. Верхнекундрюченской У.-Дон. РО в 2007 г., соб. Ю. Шумилова) (ПМДЭЭ ЮФУ: п. 84, т. 1); «Обливались у нас, Иван кода Купалы, обливались скрость. Хоть одетый идёть человек, всё равно обольють. Считалось, думали, что дождь пойдёть» (зап. от А.И. Химиной, 1914 г.р., в ст. Маркинской Цимл. РО в 1992 г.) (ПМ Б.Н. Проценко). Соответствующие мотивировки получают и действия взрослых, и поведение детей, которые, обливаясь, пели заклички: «На Ивана Купального там обливаются, да ой: “Дождик, дождик, припусти, мы поедем на кусты: Богу молиться, царю поклониться”. Это если дождя нету, на Ивана Купального вызывають. Это я знаю, что было в детстве» (зап. от К.И. Суховой, 1941 г.р., в х. Грузинове Мор. РО в 2009 г., соб. М. Кабакова) (ПМДЭЭ ЮФУ - ЮНЦ РАН: П. 98, т. 10); «Приглашать его [дождь] - приглашали. На Ивана Купалу: "Приходи к нам, приняси нам росу, полей нам поля, сделай нам урожай”» (зап. от П.М. Шмелевой, 1911 г.р., зап. в ст. Обливской Обл. РО в 1998 г., соб. Н.В. Калиничева) (ПМДЭЭ ЮФУ: п. 116, т. 2).

Особенно прагматика вызывания дождя актуализирована в тех случаях, когда обливались в поле, для чего специально везли с собой бочки с водой: «Bот мы ранъше у степи же работали, и на этот Ивана Купала понавозить водовоз воды у бощке, и тода обливаимси, купаимси» (зап. от З.В. Виноградовой, 1923 г.р., в х. Крюкове Конст. РО в 1999 г., соб. С. Ярмыш) (ПМДЭЭ ЮФУ: п. 27, т. 7); «Ранъше, кода работали в поле, то обливалися, обливалися водою, уже взрослые были, чтоб дождь пошёл» (зап. от М.В. Морозовой, 1932 г.р., ур. г. Морозовска Мор. РО, зап. в х. Волоцком Черн. ВО, в 2011 г., соб. М.Э. Тупогузова, А.А. Смирнова) (ПМДЭЭ ЮФУ - ЮНЦ РАН: п. 102, т. 1).

К этому же дню на Дону был приурочен комплекс религиозных ритуалов, нацеленных на вызывание дождя. Среди них молебны в церкви, крестные ходы по полям с молением Богу о дожде (Баг., Зим., Конст., Обл., Тар.), освящение водоемов и колодцев (ст. Красноярская Цимл.). Приведем несколько иллюстраций: «(Соб.: На Ивана Купалу освящали в Дону воду?) Раньше освящали. Батюшка панихиду служил» (зап. от Е.Ф. Кагановой, 1910 г.р., в ст. Раздорской У.-Дон. РО в 2001 г., соб. О. Карпенко) (ПМДЭЭ ЮФУ: п. 56, т. 5); «Бываеть же сушь такая, дожжа же нету. Его мы вызывали. Батюшка приезжаеть $\kappa$ колодезю, $и$ он щцитаеть молитву, опять обливаются» (зап. от 3.В. Виноградовой, в х. Крюкове Конст. РО) (ПМДЭЭ ЮФУ: п. 27, т. 7); «Вот так слышала, что вот как раз перед Ивана Купала, от это что дождей не было, тоже как-то священник там въходил, что-то там святил, ходили там с водой с этой» (зап. от Э.Е. Ульяновой, 1935 г.р., в пос. Зимовники Зим. РО в 2014 г., соб. Ю.Ю. Постникова, М.О. Костяева, О.В. Гарачук) (ПМДЭЭ ЮФУ - ЮНЦ РАН: п. 106, т. 6).

В нескольких рассказах об этих действиях упоминалось о том, что обливали священника: «На Дону на праздник Иоанна Предтечи, который известен под именем Ивана Купалы, освящают воду в колодцах, при чем присутствующие обливают друг друга водою, то же делают и с священнослужителями» (Р., 1876: 3); «Иван Купала обливалися, вот так сутра встають, так вёдры, и в реку али тут, у колодезю, $u$ обливають. И бывало, и в церкви и батюшку обольём, засмяётся и всё, такой праздникИван Купала» (респондент не указан, зап. в х. Потапове Волгод. РО в 1997 г., соб. Т. Супрунова) (ПМДЭЭ ЮФУ: П. 19, т. 8). «Это на Ивана Купала делають. Ну и тогда 
ходили с иконами, просили Господа Бога, чтобы дожжик пошёл, тоже брали с бочки воду и обливали друг друга. И священник кричить: "И мене, раб Божий, и мене облей”. Все обливаются, не брезговали нихто ничем”» (зап. от Е.А. Кисляковой, 1928 г.р., в ст. Манычской Баг. РО в 2002 г., соб. С.А. Шестак, А.С. Бабаева) (ПМДЭЭ ЮФУ: п. 14, т. 19). В последнем и в ряде других случаев ритуалистика Иванова дня демонстрирует, как в народной культуре реализуется синонимия обрядовых символов, «параллельное разнокодовое воплощение одного и того же содержания» (Толстая, 2013: 174): связь с водой задается хрононимом Иван Купала, прагматика вызывания дождя заложена в ритуальном обливании и усиливается обливанием священника.

В трех районах преодоление засухи связывалось с широко распространенными в других славянских ареалах действиями в отношении ведьм, запирающих небесные воды. Считалось, что, если облить ведьму водой, пойдет дождь: «А ишо говорили: "Хто ведьма, от её бы искупать”. Колдунья дожжа боится» (зап. от А.П. Громовой в ст. Обливской Обл. РО) (ПМДЭЭ ЮФУ - ЮНЦ РАН: П. 116, т. 2); «Вот это как на Иван Купала... смотрите, как Пришиха придёт воды набирать, давайте её обольём. Вдруг дощ пойдёт» (зап. от Е.П. Сычевой, 1934 г.р., в х. Чебачьем Сем. РО в 2008 г., соб. И. Минасян) (ПМДЭЭ ЮФУ: п. 85, т. 5); «Было такое поверие, что если на Ивана Купала облить ведъму водой, то дождъ пойдёт» (зап. от А.Ф. Филоновой, 1936 г.р., ур. Чертковского района РО, зап. в г. Цимлянске Цимл. РО, в 2000 г., соб. А.Н. Тулунова, М.Н. Костенко, М.И. Жулина) (ПМДЭЭ ЮФУ: П. 33, т. 1).

Представление о том, что в Иванов день должен пойти дождь, получило отражение и в приметах: «У нас такой ливень был и град. У нас ужасный был. $Я$ говорю: вот вам Ивана Купала! Кто-то ишо сказал: вот на Ивана Купалу прошёл сильный дождь <...> дак это не то сорок дней будеть дождь, что-то такое» (зап. от Т.И. Беспаловой, 1925 г.р., в х. Казачий Ерик Азов. РО в 2003 г.) (ПМА); «Если Иван Купала холодный дожжик идёть, так токо через пять дней солнышко засмеётся» (зап. от Ф.Г. Разогреевой, 1937 г.р., в х. Кукуевском В.-Дон. РО в 2004 г., соб.: Ерёмкина) (ПМДЭЭ ЮФУ: п. 76, т. 8).

В сохранении ритуальных действий с водой, как видится, сыграл свою роль не только фактор имени праздника, но и природный - специфика южного климата, жаркая середина лета, которые вывели проблемы засухи и ритуального от нее избавления на первый план.

Рассмотрим далее обряды Иванова дня, связанные с зеленъю. Летнее солнцестояние представляет собой время пика вегетативной активности, следствием этого является многообразие ритуальных действий с зеленью, приуроченных к Иванову дню в ряде славянских стран. Но в Ростовской и Волгоградской областях, особенно в южных районах, это самый жаркий месяц, когда температура может подниматься выше $+40{ }^{\circ} \mathrm{C}$, возможно, это обусловило относительно меньшую популярность здесь данной группы действий и верований.

Различные ритуальные действия с венками были зафиксированы нами в девяти районах PO: в ст. Елизаветинской, х. Донском, Коса, с. Кагальник Азов., х. Кукуевском В.Дон., пос. Зимовники Зим., х. Крюкове Конст., ст. Мальчевской, сл. Волошино, Колодези, Кудиновке, Нижне-Нагольной Милл., х. Юдине Милют., Парамонове, Грузинове Мор., ст. Красноярской Цимл., с. Маньково-Калитвенском Черт. В селах с восточноукраинским по происхождению населением процесс сбора зелени для венка был ритуализован: «У двориках заранее траву ходылы просыть, плылысь винкы, и всё. На Ивана Купала мы плылы винкы. $<. .>$ (Соб.: А у кого траву просили - у кого больше цветов?) Ну у тэбэ, допустим, есть, но мало. А там виноград от дикий, от таки лыстья, ты ж пойдёшь» (А. Коваленко, с. Кагальник Азов.) (ПМА). В венки вплетали красивые цветы и листья: в ст. Елизаветинской Азов. - калачики, в с. Кагальник Азов. - ромашки, листья дикого винограда, ку' дря, в с. Колодези Милл. - розу, в сл. Кудиновка Милл. - бессмертники, в ст. Мальчевской Милл. - одуванчики; в сл. Нижне-Нагольной, Волошино Милл., с. Маньково-Калитвенском Черт. - мак и ромашки (Карташова 2014: 84). В х. Мокрый Гашун Зим. в день Ивана Купалы девушки делали веночки из полевых цветов и ходили в них весь день, в ст. Мальчевской Милл. в венках прыгали через костер.

Наиболее популярным ритуальным действием с венками были гадания. Какая из метропольных традиций в данном случае выступила источником для ритуальной практики, сказать сложно, поскольку действия с венками - неотъемлемый элемент купальской 
обрядности разных групп восточных славян. Азовский и Миллеровский районы, в которых действие описывалось с обилием вариантов, - это места, где украинское по происхождению население превалирует над русским. Значительна доля украинцев в Зимовниковском и Чертковском районах; заселение территории Морозовского района происходило позже других, из разных станиц ОВД, южной России и восточной Украины. С другой стороны, в некоторых случаях решающим фактором для сохранения этого типа действий могла стать близость населенных пунктов к воде - рекам Дону, Калитве. В целом же гадания с венками в донском регионе гораздо более многочисленны в троицкий период (что характерно в первую очередь для русской традиции) и в большинстве случаев сконцентрированы именно в станицах и хуторах по течению крупных рек: Дона, Северского Донца, Маныча, Хопра, Медведицы.

По венкам, брошенным в реку, гадали о суженом: смотрели, в какую сторону поплывет венок - с той стороны будет жених (х. Коса, ст. Елизаветинская, с. Кагальник, х. Донской Азов.; ст. Мальчевская Милл., х. Парамонов Мор., ст. Нижнегниловская (ныне часть Ростована-Дону); поплывет ли вперед - это предвещало девушке скорое замужество (х. Донской Азов.); кто поймает пущенный девушкой на воду венок - тот станет ее женихом (х. Донской Азов.); наблюдали, утонет венок (это предвещало смерть), останется на поверхности воды (что предвещало замужество и благополучную жизнь) (х. Крюков Конст., пос. Зимовники, Зим.) или будет кружиться на месте («жизнь будет не совсем гладкая») (пос. Зимовники, Зuм.). Окунались в венке в реку, при этом по тому, к какому берегу поплывет оставшийся на поверхности венок, судили, в какую сторону девушка выйдет замуж (сл. Нижне-Нагольная, Волошино, Мальчевская Милл., Маньково-Калитвенское Черт. (Карташова, 2014: 84)). Вынимали венок из воды после купания и по цветку зверобоя из венка гадали: «любит не любит» (сл. Колодези Милл.).

В некоторых случаях бросание купальского венка в воду можно рассматривать в первую очередь как способ уничтожения этого обрядового атрибута (Виноградова, Толстая, 1995: 314). Ср.: «В Дон [венок кидали]. Вы купаетесь, а он поплыл на море» (зап. от М.А. Заруцкой, 1923 г.р., в х. Донском Азов. РО в 2003 г.) (ПМА).

Наряду с этим венки забрасывали на крышу, «чтобы голова не болела», не выйти замуж - «дома остаться» в этом году (с. Кагальник Азов.), приносили домой (сл. Кудиновка, сл. Колодези Милл.).

Сбор лечебных трав - одно из типичных ритуальных действий Иванова дня у русских и украинцев. Но на территории ОВД, как и гадание с венками, оно было приурочено преимущественно к Троице, а в Иванов день было зафиксировано лишь в нескольких районах: в ст. Нижнегниловской, Азовском и Константиновском районах РО, а также в Кумылженском, Михайловском, Новоаннинском и Урюпинском районах ВО. Можно предположить, что на сохранность этого ритуального действия могли влиять особенности климата степной зоны (особенно в Задонье), где уже с середины июня трава начинает сохнуть. Однако там, где травы собирали, символика Иванова дня как пика вегетации была устойчива, о чем говорит бытование в Волгоградской области хрононима Иван Травный, который фиксировали М.А. Рыблова (без указания населенного пункта) (Рыблова, 2014: 125), В.А. Апраксин в х. Сарычевском Кум. (Апраксин, 2012: 321), автор статьи и лексикографы в х. Бубновском Урюп. (ПМА; СДГВО: 214). Записанные рассказы о собирании трав содержат важные символические детали: в ст. Богоявленской Конст. сообщали, что «сорок трав, все понемножку рвали» (зап. от М.В. Харчистовой, 1915 г.р., в 2005 г.) (ПМА); в ст. Нижнегниловской бытовало присловье: «Иванов день пришёл, траву собирать пошёл» (зап. от Е.Ф. Житковой, 1920 г.р., в г. Ростове-на-Дону в 1998 г., соб. Е. Тер-Абрамян) (ПМДЭЭ ЮФУ - ЮНЦ РАН: П. 45, т. 1); в х. Рогожкино Азов. лечебные травы собирала знахарка, которая лечила людей травами, в ст. Филоновской Н.-Анн. перечисляли целебные растения, сбор которых вели на Ивана Купалу: душица, зверобой, мята (Пальгов, Шилкин, 2020: 85).

Составной частью верований, связанных с растениями и имеющих купальскую приуроченность, являются представления о чудесной силе цветка папоротника, распускающегося в канун Иванова дня. Поверья о папоротнике известны в большей части европейских традиций со средневековья (af Klintberg, 2018: 183), сведения о приуроченности поиска папоротника ко дню Ивана Предтечи содержатся также в русских травниках XVII- 
XVIII вв. и в более поздних записях народных обрядов и верований (Ипполитова, 2020: 368, 369). Это растение повсеместно наделяется мифологическими свойствами, но всё же, как правило, соотносится с одним из реальных видов: Pteridium aquilinum, Dryopteris filix-mas, Athyrium filix-femina, Botrychium lunaria, Typha angustifolia, Polypodium vulgare (af Klintberg, 2018: 181, 182, 188; Ипполитова, 2020: 369). Названные растения не типичны для степей и чаще произрастают в лесах, зарослях кустарников. В Ростовской области первые три названных вида занесены в Красную книгу (Федяева, 2014: 528, 546, 552). В нескольких случаях (Шол., Кам., Цим., У.-Дон.) ареал распространения папоротника на территории Ростовской области совпадает с локусами бытования текстов о папоротнике.

Записанные на территории ОВД тексты о папоротнике, который ищут в ночь под Ивана Купалу, в жанровом отношении можно отнести к поверьям и быличкам.

Единственный раз в Ростовской области был записан сюжет о случайном обретении цветка папоротника: «Мужчин стерёг быков, ночъю быков стерёг, днём на них работали, шёл и незаметно ему, шёл ночъю, а ему он упал в чирик, под ногу цвяток упал. (Соб.: Цветок папоротника?) Да, отломился и упал. Он и не знал. Он пришёл дамой и жене рассказываеть: “Фотя, а я знаю, о чём цыплята разговаривають, да, знаю, - говорить, и не знаю сам, почему”. Потом подметал пол, из чирика выметал сор, лазил там, и всё, он ничё не стал знать» (зап. от А.М. Яковлевой, 1928 г.р., в х. Терновском Шол. РО в 2005 г.) (ПМ Т.Е. Гревцовой).

Все остальные записанные тексты относятся к сюжетной схеме «добывание чудесного предмета» (Агапкина, 2002: 544). При этом в ряде случаев можно наблюдать контаминации сюжетов, выделенные Бенгтом аф Клинтбергом: о цветке папоротника и о кладах, о людях, которые стали обладателями ценного инструмента колдовства по соглашению с дьяволом, и легенд о других волшебных растениях (af Klintberg, 2018: 186, 188, 192).

Охарактеризуем далее основные компоненты легенд и поверий о поиске папоротника в ночь накануне Ивана Купалы. Папоротник могли искать вместе с разрыв-травой (Филипповская, Цимл. (Р., 1876: 3)). Найти его трудно: «за им охотятся» (х. Коса Азов.), «так расцветёт, что его никто не найдёт» (пос. Зимовники Зим.). Растет обычно в лесах: в Поганом лесу (сл. Кудиновка Милл.), в лесах над Донцом (ст. Митякинская Тар.), а также по садам, в байраках, при этом достигает высоты одного метра (х. Попов Кум. (Апраксин, 2012: 318-319)). Может расти прямо в реке (сл. Колодези Милл.).

Папоротник «трудно взять» (сл. Колодези Милл.) «страшно высиживать» (ст. УстьБузулукская Алекс. (Рыблова, 2014: 125)), за ним страшно ходить в одиночку (ст. Митякинская Tap.). Найти папоротник может сильный человек (ст. Филипповская Цимл.), знающий, «многие не выдерживают, не могут высидеть» (ст. Усть-Бузулукская Алекс.). Появляется цветок папоротника ночью (ст. Усть-Бузулукская Алекс.), в полночь (х. Веселый Гай Зим., сл. Кудиновка Милл., ст. Митякинская Тар., ст. Филипповская Цимл.; х. Сарычевский Кум. (Апраксин, 2012: 321)), в полночь или в час ночи (х. Табунный Мор.). Сам цветок розовый (х. Попов Кум.). Цветет по велению Господа лишь мгновение (пос. Зимовники Зим.), только час или два (х. Попов Кум.).

Чтобы увидеть папоротник, нужно описать «с заклятием около себя круг» (ст. Филипповская Цимл.), очертить вокруг себя круг, расстелить скатерть или клеенку, сесть на нее и читать в Евангелии то место, где написано о папоротнике (х. Попов Кум.); очертить у папоротника круг и сесть с вечера в этот круг. В кругу надо молиться, причем молитву надо знать особую, говорить особые заклинания (х. Сарычевский Кум.); когда брать, читать молитву (сл. Колодези Милл.).

Высиживая папоротник, человек встречается с нечистой силой, не допускающей человека к цветку: слышны шум, крик, кажется, что нападают змеи, гады, наутро место все вытоптано (ст. Филипповская Цимл.); «То табе кажется, там на тебе змеи лезуть, на тебе курица вязёть такой воз грамадный» (х. Терновской Шол.); «Огненные шары летают и катаются, разная нечисть до полуночи рычать будут, могут звери выскакивать и стараться разодрать. Человек от страха может умереть страшно, но все равно сидеть надо, молиться и твердить заклинание» (х. Сарычевский Кум. (Апраксин, 2012: 321)). Если испугаешься видений, не увидишь цветок (х. Терновской Шол.). "Черти тоже ждут и ковыряют его, и многие не выдерживают, не могут высидеть» (ст. Усть-Бузулукская Алекс.); нужно, чтобы не дотронулась до папоротника «нечистая 
рука», иначе будет плохо (пос. Зимовники Зим.); «черти стараются помешать этому: лают по-собачьи или орут из кустов “дурным" голосом, стараются напустить ветер или дождь, т. е. хотят разогнать людей» (х. Попов Кум. (Апраксин, 2012: 318-319)). Далее возможны два варианта: в первом случае кто-то вручает папоротник человеку (ст. УстьБузулукская Алекс.); во втором - человек, не выдержавший испытаний, остается ни с чем (ст. Филипповская Цимл.); Бог не допускает человека к папоротнику (сл. Кудиновка Милл.).

Если человеку удастся заполучить цветок папоротника, нужно разрезать руку и вставить его в разрез (ст. Мальчевская Милл., х. Терновской Шол., ст. Вёшенская Шол., х. Попов Кум.), рана зарастает, не оставляя шрама (х. Веселый Гай Зим., х. Сарычевский Кум.).

Получение цветка папоротника дает человеку чудесные возможности и способности: под цветком папоротника можно найти клад (ст. Гундоровская Кам.), цветок папоротника помогает найти клад (Филипповская Цимл.), дает счастье (ст. Митякинская Тар.), волшебную силу (ст. Вёшенская Шол.), мудрость и знание языка зверей и птиц (х. Антиповский, Шол. (Власкина и др., 2004: 63)). Если увидеть, когда расцветает цветок, всё будешь знать (х. Табунный Мор., х. Терновской, ст. Базковская Шол.), «будешь все знать: чужие тайны, секреты, где спрятаны клады и другое» (х. Попов Кум.)). У нашедшего будет способность открыть любой замок, взять или украсть любую вещь, обнаружить любой клад: «Ходить надо с вытянутой рукой (ладонъю вниз) и, где появится свечение, там и искать клад» (х. Сарычевский Кум. (Апраксин, 2012: 321)). Если принесешь цветок домой, никто ничего не возьмет из твоего двора (сл. Кудиновка Милл.). Сорвавшая цветок папоротника женщина, которую считали ведьмой, получила сверхъестественные способности (могла забрать тюк ткани из магазина, никто не мог остановить, попасть в другой хутор и вернуться обратно за день) (х. Веселый Гай Зим).

Целью похода может быть просто желание «поглядеть на папертный цветок» (х. Солдатовский Шол. (БТСДК: 355)). Нужен не цветок, а корень папоротника - его сок используют как растирку при болях в ногах (сл. Колодези Милл.).

Все перечисленные мотивы принадлежат славянскому (Агапкина, 2002: 544-550) и шире - европейскому репертуару (af Klinberg, 2018).

Возжигание костров, характерное для украинской традиции, было встречено в нескольких районах Ростовской и Волгоградской областей - тех, где значительная часть населения представлена выходцами из Восточной Украины. В пос. Зимовники Зим. костры устраивали на берегу реки и прыгали через них; в Миллеровском районе РО прыгали через костер прямо в воду: в пруд в ст. Мальчевской, в реку в с. Колодези. Наряду с этим два упоминания о кострах встречены и в казачьих районах: в записях 1996 г. из ст. Вёшенской Шолоховского района и в пограничном с Воронежской областью Верхнедонском. В последнем перепрыгивание через, костер сочеталось с гаданием о судьбе молодых: «В Иванов день костры жгли. Сига' ли вот молодые, ухватятся, через костёр вот так сигнуть. Значить, вам будеть счастье, значить, вы поженитесь» (зап. от А.И. Панчихиной, 1932 г.р., М.Ф. Редкокашевой, 1912 г.р., в х. Кукуевском В.-Дон. РО в 2004 г., соб. Д. Новичков) (ПМДЭЭ ЮФУ - ЮНЦ РАН: п. 76, т. 7).

Рассказы о купальских бесчинствах, симметричных святочным и известных многим европейским традициям, в обследуемом регионе записывались редко. Единожды в ст. Митякинской Тар. в отношении ночи перед Иваном Купалой использовался хрононим разгульная ночь (ПМДЭЭ ЮФУ: П. 77, т. 15). По имеющимся у автора данным, к середине $\mathrm{XX}$ в. молодежные ритуализованные бесчинства в Иванов день совершались в компактном ареале на юго-востоке бывшей ОВД - в современных Чернышковском и Котельниковском районах ВО, Зимовниковском и Обливском районах РО. В первом сообщали о том, что раньше в Иванов день молодые люди могли снять дверь или выпустить скотину (Рыблова, 2014: 125). В ст. Обливской Обл. фиксировался хрононим дурачий Купала и рассказ о том, как на Ивана Купалу хуторяне мазали соседей глиной (ПМДЭЭ ЮФУ: п. 116, т. 2). В х. Красноярском Kom., обливая друг друга, могли налить воды и в хате (Пальгов, Шилкин 2020: 84), а в пос. Зимовники Зим. тем, кто не соглашался обливаться, могли налить воду в трубу.

В нескольких населенных пунктах сохранились отголоски представлений о дне Ивана Купала как родовом празднике. Эту компоненту его символики выделил 
А.Н. Веселовский. Ученый считал, что Купала вначале был общинно-родовым праздником, знаменовавшимся браками и принятием в род, и связывал с этим обычай кумовства и посестримства (Соколова, 1979: 249). В ст. Кагальницкой Каг. были записаны воспоминания о праздничных купальских посиделках у кумовьев: «Соединялися девчата, ребята дружно все. Ну молодёжь собиралась там, песни играли, а мужики себе собираются. У кума там или у куме придуть это все, гуртом посидять» (зап. от А.П. Колесниковой) (ПМДЭЭ ЮФУ - ЮНЦ РАН: п. 110, т. 5). О семейных посиделках и трапезах сообщали в ст. Казанской В.-Дон., о гуляниях молодежи - в пос. Веселом Вес. Единожды в х. Помалинском Алекс. суббота, предшествовавшая дню Ивана Купалы, называлась поминальной, входящей в перечень семи родительских суббот (Тимофеев, 2013: 151).

Религиозная составляющая Иванова дня в записях конца XX - начала XXI вв. находится на периферии его актуальной семантики. В основном сообщения о посещении церковных служб, о проведении молебнов на полях и освящении водоемов в этот день апеллируют ко времени родителей и бабушек наших собеседников. В тех случаях, когда Иванов день воспринимается прежде всего как церковный праздник, это получает отражение и в описаниях событий, и в выборе хрононима. В ст. Кривянской Окт. сообщали, что Иванов день назывался днем Иоанна Крестителя ${ }^{1}$ в х. Осиновском Сов. - Ивана Крестителя Господня Предтечи. Кроме того, в х. Гундоровском Орл. рассказывали о церковной службе в этот день, которую посещали все хуторяне, и последующем всеобщем обливании (ПМДЭЭ ЮФУ: п. 43, т. 3). В ряде населенных пунктов (Зав., ст. Николаевской Конст., х. Мокрая Ельмута Прол., х. Козлиновском $H$-Анн.) вспоминали только о церковных службах в этот день. Кроме того, в ОВД в честь праздника Рождества Иоанна Предтечи до революции были освящены храмы в ст. Мишкинской Аксайского района и Боковской Бок. Как следствие, в последней станице на вопрос об Ивановом дне прежде всего вспоминали традиции проведения престольных праздников.

Наконец, в трех районах нам сообщили о приуроченности к Иванову дню хозяйственных работ: в х. Бубновском Урюп. в этот день готовили топливо на зиму «кизеки мяли», в х. Тормосине Черн. начинали ткать, в ст. Вёшенской Шол., пос. Нижний Чир Сур., х. Бубновском Урюп. с Иванова дня начинали покос. Появление этих мотивов можно связать с актуализацией восприятия Иванова дня как времени петровского поста, поэтому символический акцент переносился на хозяйственные работы. Такая трактовка укладывается в характерную для русских регионов особенность утраты ритуальных действий в Иванов день: согласно выводу В.К. Соколовой, «из-за поста многие элементы купальской обрядности уже давно были перенесены на Семик-Троицу» (Соколова, 1979: 250).

Иванов денъ и его символические связи с другими календарными датами. Имея присущие только ему символические и ритуальные характеристики, наряду с этим Иван Купала является частью более широкого календарного периода, «момента наивысшей точки расцвета природы» (Агапкина, 2002: 540), традиционно рассматривавшегося как троицко-купальско-петровский период. Анализируя связи Иванова дня и других праздников, автор следует концепции Т.А. Агапкиной, предложившей рассматривать народный календарь через призму мифологических доминант - общих тем (содержательных схождений), которые «пронизывают определенный календарный период, присутствуют на всем его протяжении и воплощаются во всех его жанровых формах» (Агапкина, 2002: 21). Тексты об Ивановом дне, записанные в Области войска Донского, позволяют проследить несколько таких тем. Среди них:

1. «Макушка лета» как время чудес. В ст. Каргинской Бок. автором был записан единичный текст, в котором «высиживание» волшебного цветка, позволяющего стать всезнающим, приурочено ко дню Ильи Пророка, а само цветущее растение - это не папоротник, а капуста.

2. Пик вегетативного цикла. Здесь необходимо упомянуть прежде всего сбор трав, который в ОВД осуществляли (помимо Иванова дня) в день Симона Зилота (Сухоруков, 1891: 65) и преимущественно под Троицу (Власкина, 2017; Пальгов, Шилкин, 2020: 77),

${ }^{1}$ Следствием восприятия этого праздника как религиозного, возможно, стало бытование в станице запрета на выметание мусора в этот день. 
различные ритуальные действия с венками, которые совершались как на Троицу, так и в Иванов день. В х. Бубновском Урюп. говорили, что на Ивана Травного собирали травы последний раз в году, таким образом указывая на то, что этому дню предшествовал период, когда это было возможным. Неслучайным представляется и то, что у некоторых респондентов в памяти смешивались события этих двух праздников. Так, в х. Заикинском B.-Дон. автору рассказывали о том, что Иванов день праздновали два дня, а потом появился еще и третий - Святой Дух; на первый день завивали венки, а на второй развивали.

В ст. Малая Лучка Дуб. связь Иванова дня с троицким циклом реализуется иначе: здесь Иван Купала входит в контекст Русальской недели ${ }^{1}$ «Это ж она, Русальская, на второй день, на третий день - Иван Купальный. Обливаются, ну вот эта вот молодёжь бегали, обливалися» (зап. от К.Х. Пименовой, 1918 г.р., соб. Е. Левченко); «Русальская неделя молодые вот мы были, мы обливалися вот из ведров. Иван Купала, вот это называется Русальская, это купаеть он нас» (зап. от А.М. Белавиной, 1934 г.р., соб. Е. Левченко) (ПМДЭЭ ЮФУ - ЮНЦ РАН: П. 9, т. 8). У восточных славян названный хрононим обычно связывается с Троицей (это либо неделя, предшествующая Троице, либо следующая за ней), лишь изредка встречается ассоциация ее с Ивановым днем (Моргунова и др., 2015: 367).

3. Тема защиты урожая. Рассказы о различных способах вызывания дождя, приуроченных к Иванову дню, - обливанию, обходах полей, молебнах - в гипертекстах бесед с носителями традиции часто соседствуют с рассказами об окказиональных летних обрядах той же прагматики ${ }^{2}$ Ср.: «Бегали, обливались, вот Ивана Купала, ми прибегли кодной, она сидить латаеть чё-то, ами пряма с ведра её - гугу! - водь. Глядим дожжик пошёл. Слава тебе, Господи! А потом ещё с иконами ходили у степ. Иногда настоко засуха была. Люди молились вместе с попом, шли в поля с иконами, песни распевали молебные, подводы шли с водою. <...> И идём и поём: "Христос воскрес". У нас, девочки, била', пойдём у церкви, большая церковь, пойдём у Пустошкине, у хутора, и спускаемся на Усьман. Нас встревають там жители, стол» (зап. от А.Н. Смольновой, 1912 г.р., В.Ф. Сазоновой, 1938 г.р., в ст. Манычской Баг. РО в 2002 г., соб. С.А. Шестак, А.С. Бабаева) (ПМДЭЭ ЮФУ - ЮНЦ РАН: П. 14, т. 19). Приуроченность окказиональной обрядности, направленной на преодоление засухи, к летним календарным праздникам характерна и для других южных регионов, в частности, купальские обливания и крестные ходы, имеющие целью вызывание дождя, встречались в Воронежской, Орловской областях (Пухова, Христова, 2005: 20; Соколова, 1979: 2453), в восточнославянском регионе в целом ритуальные обливания, обладающие рассматриваемой прагматикой, могли быть приурочены к разным датам троицко-купальского периода (Агапкина, 2002: 324-325).

\section{4. Заключение}

В настоящей статье мы попытались показать, что купальская обрядность донского региона - даже в своем редуцированном виде - может служить источником для выявления характерных черт региональных традиций.

Область войска Донского, как известно, представляет собой регион позднего заселения, в течение последних 500 лет почти непрерывно испытывающий приток населения из соседних областей. Естественным следствием этого было сосуществование или столкновение этнических и сословных традиций, что имело разные результаты.

Перечень и распространение основных сохранившихся в памяти респондентов действий позволяют заключить, что в целом донской вариант празднования Иванова дня ближе к характерному для русских регионов. При этом если в других русских регионах

\footnotetext{
1 Хрононим Русальская, Русальная неделя был известен и в других частях ОВД. В частности, в ст. Нижнегниловской им обозначали седьмую неделю после Пасхи.

2 Забота о сохранности урожая на территории ОВД проявлялась и огромной популярностью запретов на работу в праздники второй половине лета: в донском календарном репертуаре обеспечены многочисленными текстами так называемые страшные, наказные праздники, прежде всего дни Казанской, Смоленской икон Божией Матери, св. Пантелеймона, грозящие нарушителям запретов на работу в этот день жестокими пожарами (Шестак, 2010: 155-157).

3 Исследователь приходит к выводу о том, что «вызов дождя был одной из важных и исконных функций купального обряда» (там же).
} 
центром купальских ритуальных действий является костер (Соколова, 1979: 249), то на Дону это действия с водой, имеющие целью вызывание дождя.

В то же время большая развернутость и репрезентативность текстов о праздновании Ивана Купалы на территориях с украинской доминантой, значительным процентом неказачьего населения показывают, что более мощный культурный слой праздника, существовавший в украинской традиции, не был размыт и после переселения на Дон.

На территории нынешнего Азовского района Ростовской области казаки и крестьяне проживали в соседних населенных пунктах (это обусловлено тем, что одна часть района раньше входила в состав Екатеринославской губернии, а другая - в ОВД). Но в этническом отношении доля малороссов по происхождению была значительной и среди казаков, и среди крестьян (Матишов и др., 2012: 54). Это отразилось в комплексе купальской обрядности, где как в селах, так и в хуторах и станицах на первый план выходят различные действия с венками, фиксировалось собирание трав, даже поверье о папоротнике (при том что папоротник здесь не растет) - комплекс, характерный для украинского празднования Ивана Купалы. То же распределение ведущих мотивов, а также возжигание костров наблюдается на территории Зимовниковского района, куда в течение 150 лет постоянно направлялись потоки мигрантов из южной России и малоземельных казачьих станиц (в этническом отношении великороссы и малороссы) (Власкина, 2015: 244-247).

Наряду с этим в районах этнокультурных контактов ритуальные действия, характерные для двух соседних традиций, могут становиться и средством символического противопоставления групп населения. В рассказе из ст. Митякинской Тар., расположенной вблизи современной границы с Луганской Народной Республикой (Луганской областью Украины), местные (казачьи) и украинские (крестьянские) купальские обычаи последовательно противопоставляются как на лексическом (Иван Предтеча - Иван Купала, купальная ночь), так и на акциональном уровне (казаки купаются, ищут папоротник украинцы разжигают костёр, водят хороводы с венками и бросают их в воду, гадая по ним, купаются на рассвете для здоровья), при этом детали рассказа указывают на подробное знание традиции соседей (зап. от Н.И. Ковалёвой, 1933 г.р., в ст. Митякинской Тар. РО в 2003 г.) (ПМА).

Станицы и слободы со стабильным населением демонстрируют лучшую сохранность полноценных текстов, в то время как в более поздних по формированию населенных пунктах сведения о празднике оказываются более отрывочными.

Подводя итог, отметим, что анализ популярности мотива обливания позволил актуализировать проблему причин сохранения определенных фрагментов культуры и акцентировать роль культурной терминологии в закреплении народных верований в репертуаре территории.

\section{5. Благодарности}

Публикация подготовлена в рамках реализации ГЗ ЮНЦ РАН на 2021 г., № гр. проекта AAAA-A19-1190-11190182-8.

\section{Литература}

Агапкина, 2002 - Агапкина T.A. Мифопоэтические основы славянского народного календаря. Весенне-летний цикл. М.: Индрик, 2002. 816 с.

Апраксин, 2012 - Фольклор хопёрских казаков: материалы краеведа В.А. Апраксина / ред.-сост. И.Е. Посоха, Н.Е. Котельникова, В.Л. Кляус. М.: Государственный республиканский центр русского фольклора, 2012. 432 с.

Бондарь, 2011 - Бондарь Н.И. Календарные праздники и обряды кубанского казачества. Краснодар: Традиция, 2011. 376 с.

БТСДК - Большой толковый словарь донского казачества / Ростов. гос. ун-т; Ф-т филологии и журналистики; Каф. общ. и сравнительн. языкознания; ред.: В.И. Дегтярев, Р.И. Кудряшова, Б.Н. Проценко, О.К. Сердюкова. М.: Русские словари: Астрель: АСТ, 2003. $608 \mathrm{c}$.

Виноградова, Толстая, 1995 - Виноградова Л.Н., Толстая С.М. Венок // Славянские древности: этнолингвистический словарь: в 5 т. / под общей ред. Н.И. Толстого. Т. 1. А-Г. М.: Международные отношения, 1995. С. 314-318. 
Виноградова, Толстая, 1999 - Виноградова Л.Н., Толстая С.М. Иван Купала // Славянские древности: этнолингвистический словарь: в 5 т. / под общей ред. Н.И. Толстого. Т. 2. Д-К. М.: Международные отношения, 1999. С. 363-368.

Власкина и др., 2004 - Власкина Т.Ю., Архипенко Н.А., Калиничева Н.В. Народные знания донских казаков // Традиционная культура. 2004. № 4. С. 54-66.

Власкина, 2015 - Власкина Н.А. Народный календарь восточных славян степного Задонья в контексте миграционных процессов XIX-XX вв. // Региональные исследования в фольклористике и этнолингвистике - проблемы и перспективы / отв ред. М.В. Ахметова. М.: Государственный республиканский центр русского фольклора, 2015. С. 243-253.

Власкина, 2017 - Власкина H.A. Троицкая зелень на этнолингвистической карте бывшей области Войска Донского // Acta linguistica Petropolitana. Труды Института лингвистических исследований РАН. 2017. Т. XIII. Ч. 2. Этноботаника 2: Растения в языке и культуре. С. 191-207.

Ипполитова, 2020 - Ипполитова А.Б. Папоротник без сердца в русских рукописных травниках XVII-XVIII веков // Slavica Slovaca. 2020. Vol. 55. No. 3. P. 368-384.

Карташова, 2014 - Карташова T.А. Песенная традиция украинцев Дона в прошлом и настоящем: исследование. Ростов н/Д: Изд-во Ростовской государственной консерватории им. С.В. Рахманинова, 2014. 352 с.

Корепова, 2009 - Корепова К.Е. Русские календарные обряды и праздники Нижегородского Поволжья. СПб.: Тропа Троянова, 2009. 481 с.

Красиков и др., 1998 - Матеріали фольклорно-етнографічної експедиції «Муравський шлях - 97» (по селах Богодухівського, Валківського, Краснокутського та Нововодолазького районів) / упор. М.М. Красиков, Н.П. Олійник, В.М. Осадча, М.О. Семенова. Харків: Харьківський державний інститут культури, 1998. 360 с.

Красновская, 1978 - Красновская Н.A. Итальянцы // Календарные обычаи и обряды в странах зарубежной Европы (конец XIX - начало XX в.): летне-осенние праздники / отв. ред. С.А. Токарев. М: Наука, 1978. С. 8-19.

Матишов и др., 2012 - Социально-исторический портрет дельты Дона: казачий хутор Донской / Г.Г. Матишов, Т.Ю. Власкина, А.В. Венков, Н.А. Власкина. Ростов н/Д: Издательство ЮНЦ РАН, 2012. 216 с.

Махрачёва, Шлыкова, 2020 - Махрачёва T.В., Шлыкова М.А. Иван Купала в Тамбовской области // Живая старина. 2020. № 4. С. 16-19.

Моргунова и др., 2015 - Моргунова О.В., Кривощапова Ю.А., Осипова К.В. Русский народный календарь. Этнолингвистический словарь. М.: АСТ-пресс книга, 2015. 544 с.

Пальгов, Шилкин, 2020 - Пальгов С.Ю., Шилкин, В.А. Календарные обряды Волжского Понизовья и Подонья (по материалам фольклорных экспедиций). Волгоград: [б.и.], 2020. 169 с.

Пашина, 2003 - Смоленский музыкально-этнографический сборник. T. 1. Календарные обряды и песни / отв. ред. О.А. Пашина. М.: Индрик, 2003. 760 с.

ПМА - Полевые материалы автора.

ПМ Б.Н. Проценко - Полевые материалы Бориса Николаевича Проценко.

ПМДЭЭ ЮФУ - Полевые материалы диалектологических и этнолингвистических экспедиций Южного федерального университета (до 2006 г. - Ростовского государственного университета).

ПМДЭЭ ЮФУ - ЮНЦ РАН - Полевые материалы диалектологических и этнолингвистических экспедиций Южного федерального университета и Южного научного центра Российской академии наук.

ПМ Т.Е. Гревцовой - Полевые материалы Татьяны Евгеньевны Гревцовой.

Пухова, Христова, 2005 - Календарные обряды и обрядовая поэзия Воронежской области. Афанасьевский сборник. Материалы и исследования. Вып. III / сост. Т.Ф. Пухова, Г.П. Христова Воронеж: Изд-во ВГУ, 2005. 249 с.

Р., $1876-P$. Иванов день // Донские областные ведомости. Часть неофициальная. 1876. № 69. C. 2-3.

Рыблова, 2014 - Рыблова М.A. Календарные праздники донских казаков. Волгоград: Издатель, 2014. 168 с. 
Рожкова, Моисеева, 2003 - Календарно-обрядовый фольклор Южного Урала: сборник материалов фольклорных экспедиций лаборатории народной культуры / авт.-сост. Т.И. Рожкова, С.А. Моисеева. Магнитогорск: МаГУ, 2003. 307 с.

СДГВО - Словарь донских говоров Волгоградской области / авт.-сост. Р.И. Кудряшова, Е.В. Брысина, В.И. Супрун; под ред. проф. Р.И. Кудряшовой. Волгоград: Издатель, 2011. $704 \mathrm{c}$.

Соколова, 1979 - Соколова В.К. Весенне-летние календарные обряды русских, украинцев и белорусов. XIX - начало XX в. М.: Наука, 1979. 288 с.

Сухоруков, 1891 - Сухоруков В.Д. Статистическое описание Земли донских казаков, составленное в 1822-1832 гг. Новочеркасск: Областное правление Войска Донского, 1891. $303 \mathrm{c.}$

Тимофеев, 2013 - Материалы международных студенческих фольклорноэтнографических экспедиций Донецкого национального университета на Верхний Дон (Волгоградская и Ростовская области: 2001, 2003, 2005-2007, 2010-2012 гг.) / под общей ред. П.Т. Тимофеева. Донецк: Юго-восток, 2013. 384 с.

Толстая, 1978 - Толстая C.M. Материалы к описанию полесского купальского обряда // Славянский и балканский фольклор. Генезис. Архаика. Традиции / отв. ред. И.М. Шептунов. М.: Наука, 1978. С. 131-143.

Толстая, 2013 - Толстая C.M. Терминология обрядов и верований как источник реконструкции древней духовной культуры // Толстые Н.И., С.М. Славянская этнолингвистика: вопросы теории. М.: Институт славяноведения РАН, 2013. С. 166-181.

Толстые, 2013 - Толстой Н.И., Толстая C.M. Народная этимология и этимологическая магия // Толстые Н.И., С.М. Славянская этнолингвистика: вопросы теории. М.: Институт славяноведения РАН, 2013. С. 182-196.

Федяева, 2014 - Красная книга Ростовской области. Изд. 2-е / науч. ред. В.В. Федяева. Т. 2. Растения и грибы. Ростов н/Д: Минприроды Ростовской области, 2014. 344 с.

Черных, 2006 - Черных A.B. Русский народный календарь в Прикамье. Праздники и обряды конца XIX - середины XX в. Ч. 1. Весна, лето, осень. Пермь: Пушка, 2006. 368 с.

Шестак, 2010 - Шестак C.A. Система календарных запретов донских казаков по современным полевым материалам // Palaeoslavica. 2010. Vol. 1 (XVIII). P. 138-163.

Frazer, 2009 - Frazer J.G. The Golden Bough: A Study of Magic and Religion. Auckland: Floating Press, 2009. 1667 p.

af Klintberg, 2018 - af Klintberg B. The Wonders of Midsummer Night: Magical Bracken // Storied and Supernatural Places: Studies in Spatial and Social Dimensions of Folklore and Sagas / ed. by Ü. Valk and D. Sävborg. Helsinki: Finnish Literature Society; SKS, 2018. P. 181-193.

Paukštytė-Šaknienè, 2016 - Paukštyte்-Šakniene R. Joninės // Šventès šiuolaikinėje vilniečiu šeimoje / R. Paukštytė-Šaknienè, J. Mardosa, Ž. Šaknys, I. Šidiškienè. Vilnius: Lietuvos istorijos institutas, 2016. P. 263-290.

\section{References}

Agapkina, 2002 - Agapkina, T.A. (2002). Mifopoeticheskie osnovy slavyanskogo narodnogo kalendarya. Vesenne-letniy tsikl [Mythopoetic foundations of the Slavic folk calendar. Springsummer cycle]. M.: Indrik, 816 p. [in Russian]

Apraksin, 2012 - Posokha, I.E., Kotel'nikova, N.E., Klyaus, V.L. (eds.) (2012). Fol'klor khoperskikh kazakov: materialy kraeveda V.A. Apraksina [Folklore of the Khopyor Cossacks: materials of the local historian V.A. Apraksin]. M.: Gosudarstvennyi respublikanskii tsentr russkogo fol'klora, $432 \mathrm{p}$. [in Russian]

Bondar', 2011 - Bondar', N.I. (2011). Kalendarnye prazdniki i obryady kubanskogo kazachestva [Calendar feasts and rituals of the Kuban Cossacks]. Krasnodar: Traditsiya, 376 p. [in Russian]

BTSDK - Bol'shoy tolkovyy slovar' donskogo kazachestva [Large Dictionary of the Don Cossacks]. M: Russian Dictionaries, AST, Astrel, 2003. 608 p. [in Russian]

Chernykh, 2006 - Chernykh, A.V. (2006). Russkiy narodnyy kalendar' v Prikam'e. Prazdniki i obryady kontsa XIX - serediny XX v. Ch. 1. Vesna, leto, osen' [Russian folk calendar in the Kama region. Feasts and rituals of the late 19th - mid-2oth centuries. Part 1. Spring, summer, autumn]. Perm': Pushka, 368 p. [in Russian] 
Fedyaeva, 2014 - Fedyaeva, V.V. (ed.). Krasnaya kniga Rostovskoy oblasti. Izdanie vtoroe. T. 2. Rasteniya i griby [Red Book of the Rostov Region. $2^{\text {nd }}$ edition. Vol. 2. Plants and mushrooms]. Rostov n/D: Minprirody Rostovskoi oblasti, 344 p. [in Russian]

Frazer, 2009 - Frazer, J.G. (2009). The Golden Bough: A Study of Magic and Religion. Auckland: Floating Press, 1667 p.

Ippolitova, 2020 - Ippolitova, A.B. (2020). Paporotnik bez serdtsa v russkikh rukopisnykh travnikakh XVII-XVIII vekov [Paporotnik bez serdca in Russian Handwritten Herbals of the 17th18th centuries]. Slavica Slovaca. 55(3): 368-384. [in Russian]

Kartashova, 2014 - Kartashova, T.A. (2014). Pesennaya traditsiya ukraintsev Dona v proshlom i nastoyashchem: issledovanie [A Study of the Song tradition of Don Ukrainians in the past and present]. Rostov n/D: Izd-vo Rostovskoi gosudarstvennoi konservatorii im. S.V. Rakhmaninova, 352 p. [in Russian]

af Klintberg, 2018 - af Klintberg, B. (2018). The Wonders of Midsummer Night: Magical Bracken, Valk, U. \& Sävborg, D. (eds.). Storied and Supernatural Places: Studies in Spatial and Social Dimensions of Folklore and Sagas. Helsinki: Finnish Literature Society; SKS, pp. 181-193.

Korepova, 2009 - Korepova, K.E. (2009). Russkie kalendarnye obryady i prazdniki Nizhegorodskogo Povolzh'ya [Russian calendar rituals and feasts of the Nizhny Novgorod Volga region]. SPb.: Tropa Troyanova, 481 p. [in Russian]

Krasikov et al., 1998 - Krasikov, M.M., Oliynyk, N.P., Osadcha, V.M., Semyonova, M.O. (comp.) (1998). Materiali fol'klorno-etnografichnoï ekspeditsii "Muravs'kiy shlyakh - 97" (po selakh Bogodukhivs'kogo, Valkivs'kogo, Krasnokuts'kogo ta Novovodolaz'kogo rayoniv) [Materials of the folklore and ethnographic expedition "Muravsky Way - 97" (in the villages of Bohodukhiv, Valkiv, Krasnokutsk and Novovodolazk districts)]. Kharkiv: Khar'kivs'kii derzhavnii institut kul'turi, 360 p. [in Ukrainian]

Krasnovskaya, 1978 - Krasnovskaya, N.A. (1978). Italyantsy [The Italians]. Tokarev, S.A. (ed.) Kalendarnye obychai i obryady v stranakh zarubezhnoy Evropy (konets XIX - nachalo XX v.): letne-osennie prazdniki [Calendar customs and rites in the countries of foreign Europe (end of the 19th - beginning of the 20th century): summer-autumn holidays]. M.: Nauka, pp. 8-19. [in Russian]

Makhrachyova, Shlykova, 2020 - Makhrachyova, T.V., Shlykova, M.A. (2020). Ivan Kupala v Tambovskoy oblasti [Ivan Kupala in Tambov Region]. Zhivaya Starina. 4(108): 16-19. [in Russian]

Matishov et al., 2012 - Matishov, G.G., Vlaskina, T.Yu., Venkov, A.V., Vlaskina, N.A. (2012). Sotsial'no-istoricheskiy portret del'ty Dona: kazachiy khutor Donskoy [A Social-Historical Portrait of the Don Delta: A Cossack Hamlet of Donskoi]. Rostov n/D: Izdatel'stvo YuNTs RAN, 216 p. [in Russian]

Morgunova et al., 2015 - Morgunova, O.V., Krivoshchapova, Yu.A., Osipova, K.V. (2015). Russkiy narodnyy kalendar'. Etnolingvisticheskiy slovar' [Russian Folk Calendar: Ethnolinguistic Dictionary]. M.: AST-Press Kniga, 544 p. [in Russian]

Pal'gov, Shilkin, 2020 - Pal'gov, S.Yu., Shilkin, V.A. (2020). Kalendarnye obryady Volzhskogo Ponizov'ya i Podon'ya (po materialam fol'klornykh ekspeditsiy) [Calendar Rites of the Lower Volga and Don Regions (Based on the Materials of the Folkloric Expeditions)]. Volgograd: [s.n.], 169 p. [in Russian]

Pashina, 2003 - Pashina, O.A. (ed.) (2003). Smolenskiy muzykal'no-etnograficheskiy sbornik. T. 1. Kalendarnye obryady i pesni [Smolensk collection of music and ethnography. Vol. 1. Calendar rites and songs]. M.: Indrik, 760 p. [in Russian]

Paukštytè-Šaknienè, 2016 - Paukštyté-Šakniené, R. (2016). Joninès [Midsummer Day]. Paukštytè-Šaknienè, R., Mardosa, J., Šaknys, Ž., Šidiškienè, I. Šventès šiuolaikinèje vilniečių šeimoje. Vilnius: Lietuvos istorijos institutas, pp. 263-290. [in Lithuanian]

Pukhova, Khristova, 2005 - Pukhova, T.F., Khristova, G.P. (2005). Kalendarnye obryady i obryadovaya poeziya Voronezhskoy oblasti. Afanas'evskiy sbornik. Materialy i issledovaniya. Vyp. III [Calendar rituals and ritual poetry of the Voronezh region. Afanasyevsky collection. Materials and research. Issue III]. Voronezh: Izd-vo VGU, 249 p. [in Russian]

R., $1876-R$. (1876). Ivanov den' [St. John's Day]. Donskie oblastnye vedomosti. Chast' neofitsial'naya. 69: 2-3. [in Russian] 
Rozhkova, Moiseeva, 2003 - Rozhkova, T.I., Moiseeva, S.A. (2003). Kalendarno-obryadovyy fol'klor Yuzhnogo Urala: sbornik materialov fol'klornykh ekspeditsiy laboratorii narodnoy kul'tury. [Calendar and ritual folklore of the Southern Urals: a collection of materials of folkloric expeditions of the laboratory of folk culture]. Magnitogorsk: MaGU, 307 p. [in Russian]

Ryblova, 2014 - Ryblova, M.A. (2014). Kalendarnye prazdniki donskikh kazakov [Calendar Feasts of the Don Cossacks]. Volgograd: Izdatel', 168 p. [in Russian]

SDGVO - Kudryashova, R.I. (ed.) (2011). Slovar' donskikh govorov Volgogradskoy oblasti [Dictionary of Don dialects of the Volgograd region]. Volgograd: Izdatel', 704 p. [in Russian]

Shestak, 2010 - Shestak, S.A. (2010). Sistema kalendarnykh zapretov donskikh kazakov po sovremennym polevym materialam [The system of calendar bans of the Don Cossacks based on modern field materials]. Palaeoslavica. Vol. 1 (XVIII): 138-163. [in Russian]

Sokolova, 1979 - Sokolova, V.K. (1979). Vesenne-letnie kalendarnye obryady russkikh, ukraintsev i belorusov. XIX - nachalo XX v. [Spring-summer calendar rites of Russians, Ukrainians and Belarusians. The $19^{\text {th }}-$ early $20^{\text {th }}$ century]. M.: Nauka, 288 p. [in Russian]

Sukhorukov, 1891 - Sukhorukov, V.D. (1891). Statisticheskoe opisanie Zemli donskikh kazakov, sostavlennoe v 1822-1832 gg. [Statistical description of the Land of the Don Cossacks, compiled in 1822-1832]. Novocherkassk: Oblastnoe pravlenie Voiska Donskogo, 303 p. [in Russian]

Timofeev, 2013 - Timofeev, P.T. (ed.) Materialy mezhdunarodnykh studencheskikh fol'klorno-etnograficheskikh ekspeditsiy Donetskogo natsional'nogo universiteta na Verkhniy Don (Volgogradskaya i Rostovskaya oblasti: 2001, 2003, 2005-2007, 2010-2012 gg.) [Materials of international student folkloric and ethnographic expeditions of Donetsk National University to the Upper Don Region (Volgograd and Rostov regions: 2001, 2003, 2005-2007, 2010-2012)]. Donetsk: Yugo-Vostok, 384 p. [in Russian]

Tolstaya, 1978 - Tolstaya, S.M. (1978). Materialy k opisaniyu polesskogo kupal'skogo obryada [Materials for the description of the Polissya Kupala rite]. Sheptunov, I.M. (ed.) Slavyanskiy i balkanskiy fol'klor. Genezis. Arkhaika. Traditsii [Slavic and Balkan Folklore. Genesis. Archaic. Traditions]. M.: Nauka, pp. 131-143. [in Russian]

Tolstaya, 2013 - Tolstaya, S.M. (2013). Terminologiya obryadov i verovaniy kak istochnik rekonstruktsii drevney dukhovnoy kul'tury [Terminology of rituals and beliefs as a source of reconstruction of ancient spiritual culture]. Tolstoy, N.I., Tolstaya, S.M. Slavyanskaya etnolingvistika: voprosy teorii [Slavic ethnolinguistics: theoretical issues]. M.: Institut slavyanovedeniya RAN, pp. 166-181. [in Russian]

Tolstoy, Tolstaya, 2013 - Tolstoy, N.I., Tolstaya, S.M. (2013). Narodnaya etimologiya i etimologicheskaya magiya [Folk etymology and etymological magic]. Tolstoy, N.I., Tolstaya, S.M. Slavyanskaya etnolingvistika: voprosy teorii [Slavic ethnolinguistics: theoretical issues]. M.: Institut slavyanovedeniya RAN, pp. 182-196. [in Russian]

Vinogradova, Tolstaya, 1995 - Vinogradova, L.N., Tolstaya, S.M. (1995). Venok [Wreath]. Tolstoy N.I. (ed.). Slavyanskie drevnosti etnolingvisticheskiy slovar': v. 5 t. [Slavic Antiquities: An Ethnolinguistic Dictionary: in 5 vols.]. Vol. 1. M.: Mezhdunarodnye Otnosheniya, pp. 314-318. [in Russian]

Vinogradova, Tolstaya, 1999 - Vinogradova, L.N., Tolstaya, S.M. (1999). Ivan Kupala [St. John the Baptist (Ivan Kupala)]. Tolstoy N.I. (ed.). Slavyanskie drevnosti etnolingvisticheskiy slovar': v. 5 t. [Slavic Antiquities: An Ethnolinguistic Dictionary: in 5 vols.]. Vol. 2. M.: Mezhdunarodnye Otnosheniya, pp. 363-368. [in Russian]

Vlaskina, 2015 - Vlaskina, N.A. (2015). Narodnyy kalendar' vostochnykh slavyan stepnogo Zadon'ya v kontekste migratsionnykh protsessov XIX-XX vv. [The folk calendar of the Eastern Slavs of the steppe Trans-Don region in the context of the migration processes of the 19th-20th centuries]. Aknmetova, M.V. (ed.). Regional'nye issledovaniya v fol'kloristike i etnolingvistike problemy i perspektivy [Regional Studies in Folkloristics and Ethnolinguistics - Problems and Prospects]. M.: Gosudarstvennyi respublikanskii tsentr russkogo fol'klora, pp. 243-253. [in Russian]

Vlaskina, 2017 - Vlaskina, N.A. (2017). Troitskaya zelen' na etnolingvisticheskoy karte byvshey oblasti Voyska Donskogo [Pentecost greens on the ethnolinguistic map of the former Don Host Oblast]. Acta linguistica Petropolitana. Transactions of the Institute for Linguistic Studies. Vol. 13, part 2: 191-207. [in Russian] 
Vlaskina et al., 2004 - Vlaskina, T.Yu., Arkhipenko, N.A., Kalinicheva, N.V. (2004). Narodnye znaniya donskikh kazakov [Folk knowledge of the Don Cossacks]. Traditsionnaya kultura. 4: 54-66. [in Russian]

\section{Иванов день у донских казаков: хрононимы и ритуальные действия}

Нина Алексеевна Власкина а, *

Федеральный исследовательский центр Южный научный центр Российской академии наук, Российская Федерация

Аннотация. В статье представлен анализ лексики, обрядности и верований Иванова дня у донских казаков и крестьян. Эмпирической базой исследования послужила выборка из 126 развернутых текстов и кратких суждений, записанных в 28 районах Ростовской и 11 районах Волгоградской области. В тексте последовательно рассматриваются: основные элементы купальской обрядности в европейских и уже - восточнославянских традициях; основные символические доминанты этого дня на Дону (водная символика праздника, обряды, связанные с зеленью, возжигание костров, религиозная составляющая). Дается характеристика символических связей дня Ивана Купалы в донской традиции с днями Ильи Пророка и Симона Зилота, Троицей, окказиональным обрядом вызывания дождя. Делается вывод о том, что в целом донской вариант празднования Иванова дня ближе к характерному для русских регионов, но спецификой действий с водой является ведущая прагматика вызывания дождя. В то же время большая развернутость и репрезентативность текстов о праздновании Ивана Купалы на территориях со значительной долей украинского по происхождению населения показывает, что мощный культурный слой праздника, существовавший в украинской традиции, не был размыт и после переселения на Дон.

Ключевые слова: донские казаки, донские крестьяне, зелень, Иван Купала, купание, межэтническое взаимодействие, обливание, русские, традиционная культура, украинцы.

\footnotetext{
* Корреспондирующий автор

Адреса электронной почты: nvlaskina@gmail.com (Н.А. Власкина)
} 